\title{
Bioakumulasi Logam Berat Merkuri (Hg) Pada Mangrove Jenis Rhizophora Mucronata Di Teluk Kayeli Kabupaten Buru
}

\author{
Irwan Ismail ${ }^{1}$, Rosita Mangesa ${ }^{2 *}$ Irsan $^{2}$ \\ ${ }^{1}$ Program Studi Budidaya Perairan, Fakultas Perikanan Dan Ilmu Kelautan \\ Universitas Iqra Buru \\ ${ }^{2}$ Program Studi Pendidikan Biologi, Fakultas Keguruan dan Ilmu Pendidikan \\ Universitas Iqra Buru \\ *Email: rositamangesa5@gmail.com
}

\begin{abstract}
Abstrak: Teluk Kayeli adalah suatu perairan di Kabupaten Buru yang mempunyai nilai yang sangat penting ditinjau dari fungsi ekologis serta fungsi ekonomis. Dalam perkembangannya, ekosistem pada Teluk Kayeli menanggung beban pencemaran terutama logam berat merkuri akibat dari pertambangan emas rakyat di Pulau Buru yang menggunakan $\mathrm{Hg}$ untuk mendapatkan emas murni. $\mathrm{Hg}$ dapat terakumulasi di lingkungan terutama mengendap di sedimen di perairan Teluk Kayeli. Tumbuhan mangrove yang secara umum tumbuh pada lingkungan muara dan tepi pantai merupakan tempat penumpukan sedimen. Tumbuhan ini memiliki kemampuan untuk menyerap dan mengakumulasi logam berat salah satunya adalah jenis $R$. mucronata. Penelitian ini bertujuan untuk menganalisis konsentrasi logam berat $\mathrm{Hg}$ pada mangrove $R$. mucronata dan sedimen, serta menganalisis bioakumulasi logam berat $\mathrm{Hg}$ pada $R$. mucronata di Teluk Kayeli Kabupaten Buru. Sampel diambil dari 3 stasiun, yaitu Muara Sungai Anahoni (Stasiun I), Muara Sungai Wailata (Stasiun II) dan Muara Sungai Waeapo (Stasiun III). Setiap stasiun terdapat 2 titik (ulangan) pengambilan sampel. Penentuan konsentrasi logam $\mathrm{Hg}$ pada sampel menggunakan metode $C V$-AAS. Nilai rata-rata konsentrasi $\mathrm{Hg}$ pada akar lebih tinggi dari kulit batang dan daun mangrove $R$. mucronata, namun konsentrasinya lebih rendah dari sedimen dan masih dibawah nilai kritis logam $\mathrm{Hg}$ untuk tanaman. Nilai rata-rata konsentrasi $\mathrm{Hg}$ sedimen masih dibawah standar baku mutu sedimen. Tanaman mangrove $R$. mucronata dalam penelitian bersifat Excluder dan fitostabilisasi, dimana terjadi pembatasan penyerapan logam berat $\mathrm{Hg}$ dari air dan sedimen dan akumulasi $\mathrm{Hg}$ terbanyak terdapat pada akar.
\end{abstract}

Kata Kunci: Bioakumulasi, Merkuri, Rhizophora mucronata, Teluk Kayeli

BIOLOGI SEL (VOL 9 NO 2 EDISI JUL-DES 2020 ISSN 2252-858X/E-ISSN 2541-1225) PAGE 139 


\begin{abstract}
Kayeli Bay is a water in Buru Regency which has very important value in terms of ecological and economic functions. During its development, the ecosystem in Kayeli Bay bears the burden of pollution, especially heavy metal mercury as a result of the people's gold mining on Buru Island which uses $\mathrm{Hg}$ to get pure gold. $\mathrm{Hg}$ can accumulate in the environment, especially deposited in the sediments in Kayeli Bay waters. Mangrove plants that generally grow in estuary and coastal environments are a place for sediment accumulation. This plant has the ability to absorb and accumulate heavy metals, one of which is $R$. mucronata. This study aims to analyze the concentration of heavy metal $\mathrm{Hg}$ in mangroves of $R$. mucronata and sediments, and to analyze the bioaccumulation of heavy metal $\mathrm{Hg}$ in $R$. mucronata in Kayeli Bay, Buru Regency. Samples were taken from 3 stations, namely the Anahoni River Estuary (Station I), the Wailata River Estuary (II Station) and the Waeapo River Estuary (III Station). Each station has 2 sampling points (replicates). Determination of the concentration of $\mathrm{Hg}$ metal in the sample using the CVAAS method. The average value of $\mathrm{Hg}$ concentration in the roots was higher than the bark and leaves of the mangrove $R$. mucronata, but the concentration was lower than the sediment and was still below the critical value of $\mathrm{Hg}$ for plants. The average value of sediment $\mathrm{Hg}$ concentration is still below the sediment quality standard. In this study, $R$. mucronata mangroves were excluder and phytostabilized, where there was a limitation on the absorption of heavy metal $\mathrm{Hg}$ from water and sediment and the most $\mathrm{Hg}$ accumulation was found in the roots.
\end{abstract}

\title{
Keywords: Bioaccumulation, Mercury, Rhizophora mucronata, Kayeli Bay
}

Teluk Kayeli merupakan perairan yang terdapat di Kabupaten Buru Provinsi Maluku dan terletak antara $3^{0} 15^{\prime} 55^{\prime}$ ' $-3^{0} 22^{\prime} 50^{\prime \prime} \mathrm{S}$ dan $127^{0} 01^{\prime} 35^{\prime \prime}-127^{0} 01^{\prime} 35^{\prime \prime}$ T. Teluk ini memegang peran penting sebagai habitat berbagai jenis organisme air, wilayah budidaya perikanan serta penunjang ekosistem mangrove. Dalam perkembangannya Teluk Kayeli mengalami berbagai permasalahan terutama pencemaran logam berat merkuri akibat hadirnya pertambangan emas rakyat Gunung Botak, Gunung Anahoni dan Desa Gogorea yang dimulai sejak akhir bulan September 2011. Pencemaran Hg ini disebabkan karena limbah (tailing) pengolahan emas yang mengandung $\mathrm{Hg}$ dari pertambangan emas rakyat dibuang ke lingkungan terutama pada sungai-sungai yang bermuara pada Teluk Kayeli tanpa penanganan khusus. Beberapa penelitian sebelumnya menunjukan bahwa Teluk Kayeli telah terkontaminasi merkuri terutama pada wilayah yang berada di sekitar muara sungai (Male., et all, 2013; Natsir., dkk, 2019; Irsan.,dkk, 2020).

BIOLOGI SEL (VOL 9 NO 2 EDISI JUL-DES 2020 ISSN 2252-858X/E-ISSN 2541-1225) PAGE 140 
Merkuri atau raksa yang dilambangkan $\mathrm{Hg}$ merupakan logam berat yang digolongkan sebagai pencemar paling berbahaya, karena bersifat neutrotoksin, baik untuk organisme maupun manusia (Gochfeld, 2003). Hg yang masuk dalam lingkungan perairan selain terkonsentrasi pada air juga akan mengendap pada sedimen. Merkuri dapat mengalami berbagai transformasi dalam lingkungan dan selanjutnya dapat terakumulasi dalam jaringan tubuh biota diantaranya tumbuhan melalui proses bioakumulasi (He et al., 2007). Proses bioakumulasi logam berat secara kimiawi merupakan reaksi pembentukan senyawaan kompleks antara logam berat dengan sel-sel organisme yang berfungsi sebagai ligan (Liu et al., 2012).

Organisme perairan yang dapat menerima dampak langsung pencemaran logam $\mathrm{Hg}$ pada Teluk Kayeli adalah tanaman mangrove, sebab tanaman ini banyak dijumpai di wilayah Teluk Kayeli terutama pada wilayah muara sungai dan pesisir pantai. Vegetasi mangrove sendiri memiliki banyak fungsi ekologi seperti tempat mencari makan, memijah dan berkembang biak bagi udang dan ikan serta kerang dan kepiting. Disamping itu, vegetasi mangrove mempunyai kemampuan mengakumulasi logam berat dan membantu mengurangi tingkat konsentrasi bahan pencemar di lingkungan perairan. Parvaresh et al (2010) menyebutkan bahwa selain dapat terakumulasi dalam sedimen, logam berat juga dapat terakumulasi dalam struktur mangrove.

Salah satu jenis mangrove yang dapat menyerap kandungan logam berat di alam adalah Rizhophora mucronata. Mangrove jenis ini banyak hidup di wilayah muara sungai dan pesisir pantai Teluk Kayeli. Pahalawattaarachchi et all (2009) menjelaskan mangrove Rizhophora mucronata dapat berperan sebagai agen bioremediasi logam berat karena dapat menyerap dan mengakumulasi logam. Rizhophora mucronata memiliki akar penyangga, selain fungsinya untuk membantu tegaknya pohon, akar jenis ini juga dapat menahan dan memantapkan sedimen tanah, sehingga mencegah tersebarnya bahan pencemar ke area yang lebih luas. Oleh karena itu akar mangrove jenis ini dapat lebih optimal dalam menyerap logam berat. Berbagai penelitian telah menunjukan $R$. mucronata dapat mengakumulasi logam berat dan berperan sebagai agen bioremediasi, namun penelitian mengenai bioakumulasi logam berat $\mathrm{Hg}$ yang secara khusus pada $R$. mucronata belum banyak dilakukan, sehingga masih perlu kajian yang mendalam. Tujuan dalam penelitian ini yaitu untuk menganalisis konsentrasi logam berat $\mathrm{Hg}$ pada mangrove $R$. mucronata dan sedimen, serta menganalisis bioakumulasi logam berat $\mathrm{Hg}$ pada $R$. mucronata di Teluk Kayeli Kabupaten Buru. 


\section{METODE PENELITIAN}

Penetapan stasiun pengambilan sampel menggunakan Geographic Positioning System (GPS) tipe Garmin 610 yang ditentukan secara purposive sampling, yakni dengan pertimbangan daerah pada Teluk Kayeli yang memiliki konsentrasi merkuri tertinggi pada sedimen di beberapa penelitian sebelumnya, merupakan aliran pembuangan limbah dan terdapat spesies mangrove $R$. mucronata. Stasiun pengambilan sampel dibagi menjadi 3 stasiun yaitu: Stasiun 1 (Muara Sungai Anahoni); Stasiun 2 (Muara Sungai Wailata) dan Stasiun 3 (Muara Sungai Waeapo). Setiap stasiun terdapat dua titik sampling. Peta lokasi peneltian ditunjukan pada gambar 1.

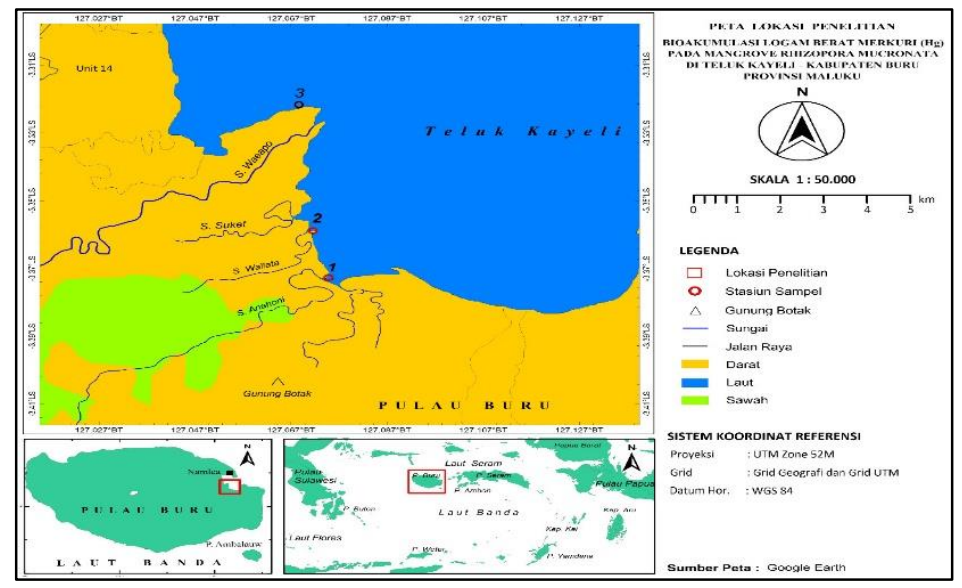

Gambar 1. Peta Lokasi pengambilan sampel di Teluk Kayeli Kabupaten Buru.

Sampel $R$. mucronata yang diambil terdiri atas akar, kulit batang dan daun. Mangrove yang dipilih adalah mangrove sudah dikategorikan sebagai pohon dengan ukuran diameter batang kurang lebih $15-25 \mathrm{~cm}$. Akar yang akan diambil berdiameter sekitar $1 \mathrm{~cm}$ dengan panjang sekitar $15-20 \mathrm{~cm}$. Pada setiap ulangan, akar diambil dari 1 pohon mangrove dengan jumlah 10 akar. Sampel kulit batang yang diambil adalah yang terkena pasang surut air laut dengan ukuran panjang $5 \mathrm{~cm}$ dan lebar $5 \mathrm{~cm}$, dimana setiap ulangan (pohon) diambil sebanyak 3 kulit batang. Sampel daun yang diambil adalah daun tua berwarna hijau yang terletak pada cabang pertama pohon dengan ukuran panjang sekitar $10 \mathrm{~cm}$ dan lebar $5 \mathrm{~cm}$. Disetiap ulangan diambil dari 1 pohon mangrove dengan jumlah 10 daun (Arisandy, dkk, 2012).

Pengambilan sedimen dengan metode Integrated Composite dan dilakukan dua kali pengulangan (Suheryanto, dkk, 2013). Pengambilan sampel sedimen menggunakan pipa PVC berdiameter $10 \mathrm{~cm}$ dengan panjang $200 \mathrm{~cm}$. Pipa PVC dimasukkan ke dalam 
sedimen sehingga mencapai kedalaman $\pm 30 \mathrm{~cm}$ secara vertikal. Sampel yang diambil sebanyak $1 \mathrm{~kg}$ (Jupriyati, dkk, 2013). Untuk satu ulangan terdapat 3 titik tempat pengambilan sampel sedimen. Sampel dari masing-masing titik tersebut dicampur untuk mendapatkan 1 komposit sampel. Sampel mangrove dan sedimen yang telah diambil disimpan pada plastic strap, diberi label kemudian dimasukkan ke dalam kotak pendingin (coolbox). Sampel disimpan dalam ruang beku (freezer) dengan suhu $0^{\circ} \mathrm{C}$ sebelum dianalisis di laboratorium.

Sampel sedimen dibersihkan dari kotoran serasah/cangkang kerang, kemudian dikeringkan dalam oven selama 72 jam dengan suhu $40^{\circ} \mathrm{C}$. Sampel akar, kulit batang dan daun mangrove dipotong kecil-kecil terlebih dahulu kemudian dicuci dengan air suling dan dikeringkan dalam oven pada suhu $40^{\circ} \mathrm{C}$ selama 48 jam hingga kering. Sampel sedimen, akar, kulit batang dan daun mangrove yang telah kering kemudian dihaluskan dengan menggunakan mortar dan alu. Sebanyak 0,5 gram sampel sedimen halus dimasukan ke dalam gelas piala $100 \mathrm{~mL}$. Ditambahkan $5 \mathrm{~mL} \mathrm{HNO}_{3}$ pekat, dihomogenkan, kemudian ditutup dengan kaca arloji, dididihkan secara perlahan di atas hotplate pada suhu $95^{\circ} \mathrm{C}$. Ketika volume larutan tersisa $15-20 \mathrm{~mL}$ gelas piala diangkat dari hotplate kemudian didinginkan. Setelah dingin, ditambahkan $10 \mathrm{~mL} \mathrm{HNO}_{3}$ pekat dan $10 \mathrm{~mL} \mathrm{HClO}_{4}$, selanjutnya larutan dihomogenkan dan kembali dipanaskan di atas hotplate sampai uap $\mathrm{HClO}_{4}$ hilang. Larutan didinginkan dan ditambahkan $50 \mathrm{~mL}$ air suling. Dinding piala gelas dan kaca arloji yang digunakan untuk menutup dibilas dengan air suling. Larutan disaring seraya dibilas dengan air suling sampai diperoleh volume filtrat $100 \mathrm{~mL}$, kemudian larutan dihomogenkan dan selanjtnya di analisis dengan alat AAS cold vapor. Alat dan metode yang digunakan untuk ekstraksi dan analisis logam berat merkuri pada sedimen sama dengan pada akar, kulit batang dan daun mangrove.

Data konsentrasi logam berat $\mathrm{Hg}$ yang diperoleh ditampilkan dalam bentuk tabel dan grafik kemudian akan dibahas secara deskriptif. Untuk menentukan kondisi logam berat Hg pada mangrove Rizhophora mucronata, maka hasil analisis $\mathrm{Hg}$ di laboratorium dibandingkan dengan kisaran Hg pada tanaman berdasarkan Alloway and Ayres (1995). Untuk menentukan kondisi logam berat merkuri pada sedimen dilihat berdasarkan Kriteria Baku Mutu konsentrasi logam berat dalam sedimen perairan berdasarkan ANZECC/AMRCANZ (2000), sedangkan untuk melihat bioakumulasi logam berat $\mathrm{Hg}$ pada tanaman mangrove Rizhophora mucronata dilakukan perhitungan BCF (Bioconcentration factor) dan TF (Translocation Factor).

Analisis BCF dilakukan untuk mengetahui tingkat akumulasi logam berat $\mathrm{Hg}$ dari sedimen ke tanaman mangrove Rizhophora mucronata. Rumus perhitungan BCF oleh Yoon et al (2006) yaitu:

BIOLOGI SEL (VOL 9 NO 2 EDISI JUL-DES 2020 ISSN 2252-858X/E-ISSN 2541-1225) PAGE 143 


$$
\mathrm{BCF}=\frac{C_{H g} \text { pada jaringan tanaman }(\mathrm{mg} / \mathrm{kg})}{C_{H g} \text { pada sedimen }(\mathrm{mg} / \mathrm{kg})}
$$

Dengan katagori tanaman dibagi menjadi 3, yaitu:

1. Akumulator: Apabila nilai $\mathrm{BCF}>1$

2. Excluder: Apabila nilai $\mathrm{BCF}<1$

3. Indikator: Apabila nilai BCF mendekati 1.

Faktor Translokasi (TF) adalah nilai perbandingan kandungan logam berat pada daun dan akar. Nilai TF dihitung untuk mengetahui perpindahan akumulasi logam dari akar ke bagian daun (MacFarlane et al., 2003). TF dapat dihitung dengan rumus:

$$
\mathrm{TF}=\frac{C_{\text {Hg pada daun }(\mathrm{mg} / \mathrm{kg})}}{C_{\text {Hg pada dakar }(\mathrm{mg} / \mathrm{kg})}}
$$

Nilai TF menurut (Majid et al., 2014) memiliki dua kategori yaitu :

$\mathrm{TF}>1$ : Mekanisme fitoekstraksi

$\mathrm{TF}<1$ : Mekanisme fitostabilisasi.

\section{HASIL DAN PEMBAHASAN}

\section{Konsentrasi Merkuri Pada Akar, Kulit Batang dan Daun Mangrove R. mucronata}

Hasil pengukuran konsentrasi logam berat $\mathrm{Hg}$ pada akar, kulit batang, daun mangrove $R$. mucronata dapat dilihat pada tabel 1 .

\begin{tabular}{|c|c|c|c|c|}
\hline \multirow{2}{*}{$\begin{array}{c}\text { Sampel } \\
\text { Mangrove }\end{array}$} & \multicolumn{3}{|c|}{ Konsentrasi Hg (ppm) } & \multirow{2}{*}{$\begin{array}{c}\text { Konsentrasi kritis Logam } \mathrm{Hg} \\
\text { (ppm) Pada Tanaman* }\end{array}$} \\
\hline & $\begin{array}{l}\text { St.I } \\
\end{array}$ & St.II & St.III & \\
\hline Akar & 0,021 & 0,012 & 0,035 & \\
\hline Kulit batang & 0,001 & 0,003 & $<0,0001$ & $0,3-0,5$ \\
\hline Daun & $<0,0001$ & $<0,0001$ & $<0,0001$ & \\
\hline
\end{tabular}

Tabel 1. Rata-Rata Konsentrasi Hg pada Akar, Kulit Batang dan Daun Mangrove R. mucronata

Tabel 1 menunjukan konsentrasi logam berat merkuri tertinggi terdapat pada akar mangrove $R$. mucronata, sedangkan pada daun dibawah deteksi limit (DL) alat yang digunakan untuk penentuan logam berat $\mathrm{Hg}$. Untuk kulit batang, konsentrasi $\mathrm{Hg}$ ditemukan di stasiun I dan stasiun II, sementara di stasiun III tidak tidak terdeteksi (<0,0001 ppm). Terdapatnya konsentrasi merkuri pada akar dan kulit batang $R$. mucronata menunjukan bahwa, secara alami mangrove dapat menyerap kandungan logam berat di alam dan fungsi ini disebut sebagai biosorbsi (Hastuti dkk, 2013). Menurut Hardiani (2009), besarnya akumulasi logam pada akar merupakan salah satu mekanisme detoksifikasi yang dilakukan tanaman untuk menghindari keracunan dan kerusakan oleh logam pada sel tanaman.

BIOLOGI SEL (VOL 9 NO 2 EDISI JUL-DES 2020 ISSN 2252-858X/E-ISSN 2541-1225) PAGE 144 
Mangrove dapat menyerap polutan organik maupun non organik dari lingkungannya kedalam tubuhnya menggunakan membrane sel. Ini merupakan bentuk adaptasi dari mangrove terhadap kondisi lingkungan yang tercemar. Ini sesuai dengan penjelasan (Pahalawattaarachchi et al, 2009) Rizhophora mucronata merupakan salah satu jenis tumbuhan mangrove yang dapat berperan sebagai agen bioremediasi logam berat.

Tingginya konsentrasi merkuri pada akar sesuai dengan temuan Tam dan Wong (Utami dkk, 2018), dimana kandungan logam berat pada mangrove lebih banyak ditemukan di perakaran mangrove. Kondisi ini diduga karena jaringan akar mempunyai interaksi langsung dengan sedimen dan air yang telah terkontaminasi oleh logam berat yang mengendap, kemudian ditranslokasikan ke bagian lain. Menurut Lakitan (2001), unsur hara dapat kontak dengan permukaan akar melalui tiga cara, yakni secara difusi dalam larutan tanah, secara pasif terbawa aliran air tanah dan karena akar kontak dengan hara tersebut di dalam matriks tanah.

Nilai rata-rata konsentrasi merkuri tertinggi pada akar di setiap staisun secara berurutan yaitu: stasiun I berjumlah $0,035 \mathrm{ppm}$, stasiun II 0,0115 ppm dan stasiun III sebanyak 0,035 ppm. Tingginya konsentrasi $\mathrm{Hg}$ pada akar di stasiun III dimungkinkan karena sebagain besar $\mathrm{Hg}$ pada sedimen di stasiun ini terakumulasi pada organ tanaman mangrove tersebut. Ini sejalan dengan stasiun I dan stasiun II dimana konsentrasi $\mathrm{Hg}$ pada sedimen tinggi, namun ditemukan konsentrasi yang lebih rendah pada akar.

Rata-rata Konsentrasi merkuri tertinggi pada kulit batang $R$. mucronata terdapat pada stasiun II dengan jumlah 0,003 ppm, disusul stasiun I dengan jumlah 0,001 ppm dan tidak terdeteksi pada stasiun III. Terdapatnya perbedaan konsentrasi Hg pada kulit batang diduga berhubungan dengan konsentrasi merkuri pada akar. Untuk stasiun I dan stasiun II konsentrasi $\mathrm{Hg}$ lebih rendah pada akar apabila dibandingkan dengan stasiun III. Ini menunjukan meskipun $\mathrm{Hg}$ terkonsentrasi pada akar, namun terjadi pula distibusi $\mathrm{Hg}$ ke bagian kulit batang. Hal ini dipertegas oleh Hardiani (2009), dimana secara umum tumbuhan melakukan penyerapan oleh jaringan akar, baik yang berasal dari sedimen maupun air, kemudian terjadi translokasi ke bagian tumbuhan yang lain dan lokalisasi atau penimbunan logam pada jaringan tertentu. Terdapatnya sampel kulit batang yang tidak terdeteksi $\mathrm{Hg}$, mengindikasikan bahwa, meskipun merupakan satu sepesies, namun sampel diambil dari pohon yang berbeda sehingga dapat mempengaruhi kemampuan dalam menyerap atau mendidtibusikan loham $\mathrm{Hg}$.

Konsentrasi merkuri pada daun $R$. mucronata pada semua stasiun penelitian tidak terdeteksi (dibawah deteksi limit) alat yang digunakan, yaitu sebesar 0,004 ppm. Dijelaskan oleh Hardiani (2009), secara umum tumbuhan melakukan penyerapan oleh 
jaringan akar, baik yang berasal dari sedimen maupun air, kemudian terjadi translokasi ke bagian tumbuhan yang lain dan lokalisasi atau penimbunan logam pada jaringan tertentu. Ini memungkinkan tidak terdeteksi $\mathrm{Hg}$ pada daun karena penimbunan $\mathrm{Hg}$ terjadi pada akar. Priyanto dan Prayitno (2004) menjelaskan, sebagai upaya untuk mencegah keracunan logam terhadap sel dan jaringan, tumbuhan mempunyai mekanisme detoksifikasi, misalnya dengan menimbun logam di dalam organ tertentu seperti akar. Adanya akumulasi logam merupakan usaha lokalisasi yang dilakukan oleh tumbuhan, dengan mengumpulkan dalam satu organ (Heriyanto dan Endro, 2011). Dalam sel tumbuhan logam melewati plasmalema, sitoplasma, dan vakuola, dimana logam akan dilokalisasi/terakumulasi dalam vakuola. Bagian vakuola menjaga agar logam tidak menghambat metabolisme tumbuhan (Priyanto dan Prayitno, 2004). Pada jaringan akar, logam masuk korteks dan diakumulasi di dekat endodermis. Endodermis berfungsi sebagai partial barrier terhadap pemindahan logam dari akar (Siswanto, 2009). Hal ini yang diduga sebagai salah satu alasan adanya akumulasi logam lebih besar di akar.

Konsentrasi logam berat merkuri pada akar, kulit batang dan daun mangrove $R$. mucronata yang diperoleh dalam penelitian masih dibawah nilai kritis logam $\mathrm{Hg}$ untuk tanaman berdasarkan Alloway and Ayres (1995) yaitu berada pada kisaran nilai 0,3 - 0,5 ppm. Ini berarti konsentrasi $\mathrm{Hg}$ tidak berbahaya pada tanaman mangrove R. mucronata.

\section{Konsentrasi Mekuri Pada Sedimen}

Sedimen memiliki arti sebagai transport merkuri, menyebabkan terjadinya sebaran merkuri. Hasil analisis konsentrasi logam berat merkuri pada sedimen disemua stasiun penelitian ditunjukan pada tabel 2 .

Tabel 2. Nilai Rata-Rata Konsentrasi Merkuri pada Sedimen Di Semua Stasiun Penelitian

\begin{tabular}{cccc}
\hline $\begin{array}{c}\text { Stasiun } \\
\text { Penelitian }\end{array}$ & $\begin{array}{c}\text { Konsentrasi Hg } \\
(\mathbf{p p m})\end{array}$ & Tipe Sedimen & $\begin{array}{c}\text { *Nilai Baku mutu } \\
(\mathbf{m g} / \mathbf{k g})\end{array}$ \\
\hline St.I & 0,237 & Pasir berlumpur & \\
St.II & 0,233 & Pasir berlumpur & 1,0 \\
St.III & 0,217 & Pasir halus & \\
\hline
\end{tabular}

*ANZECC/AMRCANZ, 2000.

Beradasarkan Tabel 2 diketahui konsentrasi merkuri terdeteksi pada sedimen disemua stasiun penelitian. Amin dkk (2009) menjelaskan sebagian besar logam berat yang terkontaminasi pada lingkungan perairan akan terendap pada sedimen. Merkuri memiliki sifat yang mudah mengikat bahan organik dan mengendap di dasar perairan, sehingga konsentrasi merkuri di sedimen tinggi. Ini sesuai dengan temuan sedimen memiliki konsentrasi $\mathrm{Hg}$ yang paling tinggi dibandingkan dengan akar, kulit batang dan daun mangrove $R$. mucronata (tabel 1). Kondisi ini terjadi melalui proses akumulasi bahanbahan yang tidak larut dalam air yang selanjutnya terendapkan di dasar perairan. Hasil 
penelitian ini sejalan dengan beberapa penelitian sebelumnya, Irsan dkk (2020) menemukan konsentrasi merkuri pada sedimen di Sungai Waelata dan Sungai Anahoni lebih tinggi dibandingkan dengan kolom air dan kerang Polymesoda erossa. Natsir dkk (2019) menemukan akumulasi $\mathrm{Hg}$ lebih banyak terdapat pada sedimen dibandingkan air dan organ lamun Enhalus acoroides (akar, rhizoma dan daun) di Perairan Teluk Kayeli.

Rata-rata konsentrasi merkuri tertinggi terdapat pada stasiun I dengan jumlah sebanyak 0,237 ppm, disusul stasiun II dengan 0,233 ppm dan terendah pada stasiun III dengan jumlah 0,217 ppm. Perbedaan konsentrasi $\mathrm{Hg}$ pada setiap stasiun penelitian diduga berhubungan dengan tipe sedimen. Sedimen yang memiliki konsentrasi tertinggi (stasiun I dan stasiun II) memiliki tipe sedimen pasir berlumpur, sedangkan stasiun III dengan konsentrasi merkuri terendah memiliki tipe sedimen pasir halus (tabel 2). Temuan ini sejalan dengan Irsan., dkk (2020) bahwa tipe sedimen mempengaruhi konsentrasi $\mathrm{Hg}$, dimana konsentrasi Hg tertinggi terdapat pada sedimen yang di dominasi lumpur dibandingkan dengan tipe sedimen berpasir. Lumpur merupakan sedimen yang kaya akan bahan organik dan mudah berikatan dengan merkuri, kemudian mengendap di dasar perairan.

Selain tipe sedimen, tingginya rata-rata kandungan merkuri sedimen pada stasiun I dibandingkan dengan stasiun yang lain diduga berhubungan dengan jarak stasiun dengan sumber merkuri dari PETI dan unit pengolahan trommel. Dijelaskan oleh Irsan., dkk (2020) muara sungai Anahoni memiliki jarak yang lebih dekat dengan tempat aktivitas pertambangan emas tradisional di Gunung Botak dan lokasi trommel dibandingkan dengan muara Sungai Waelata dan muara Sungai Waeapo. Jarak yang lebih dekat dengan lokasi PETI akan memiliki kadar Hg yang lebih besar dibandingkan dengan jarak yang jauh dari sumber (kegiatan penambangan). Dengan demikian, Sungai Anahoni berpotensi memiliki akumulasi logam $\mathrm{Hg}$ yang relatif lebih besar dibandingkan dengan Sungai Waelata dan muara Sungai Waeapo. Fakta ini sesuai dengan hasil penelitian yang mengungkapkan bahwa konsentrasi merkuri dalam sedimen cenderung menurun dengan semakin jauh jarak dari sumber kontaminasi (Feng \& Qiu, 2008).

Secara umum kadar logam berat merkuri $(\mathrm{Hg})$ pada sedimen yang ada di setiap stasiun menunjukkan kisaran yang masih dibawah standar baku mutu sedimen berdasarkan ANZECC/AMRCANZ (2000) sebesar 1,0 mg/kg (ppm). Ini menunjukan, logam berat merkuri pada sedimen tidak terlalu berbahaya bagi lingkungan. Meskipun demikian, apabila penggunaan merkuri terus terjadi lewat kegiatan pertambangan emas dengan sistem amalgamasi, terutama pada DAS Anahoni, DAS Waelata dan DAS Waeapo, maka kadar merkuri di sedimen bisa saja akan meningkat seiring dengan penggunaannya dan dapat mencapai level berbahaya, sehingga perlu diwaspadai.

BIOLOGI SEL (VOL 9 NO 2 EDISI JUL-DES 2020 ISSN 2252-858X/E-ISSN 2541-1225) PAGE 147 


\section{Nilai Bioaccumulation Factor (BCF)}

BCF merupakan cara untuk mengetahui akumulasi logam berat $\mathrm{Hg}$ dalam tanaman. Nilai BCF yang diperoleh akan dibandingkan dengan standar peritungan BCF yang dikemukakan oleh Yoon at all (2006), dimana nilai BCF yang lebih dari satu merupakan tanaman akumulator, sedangkan nilai BCF tanaman yang mendekati satu merupakan tanaman Indikator dan nilai BCF tanaman yang kurang dari satu merupakan excluder. Hasil perhitungan BCF tanaman mangrove Rizhophora mucronata dapat dilihat pada tabel 3.

Tabel 3. Nilai BCF Tanaman Mangrove Rizhophora mucronata

\begin{tabular}{cccc}
\hline Stasiun & C daun+ kulit batang +akar $_{\text {da }}$ & $\mathbf{C}_{\text {sedimen }}$ & Nilai \\
\hline St.I & 0,022 & 0,237 & 0,09 \\
St.II & 0,042 & 0,233 & 0,18 \\
St.III & 0,035 & 0,217 & 0,16 \\
\hline
\end{tabular}

Tabel 3 menunjukan nilai BCF tertinggi terdapat pada stasiun II yaitu sebesar 0,18 , sedangkan nilai BCF terendah terdapat pada stasiun I sebesar 0,16. Nilai BCF pada ketiga stasiun kurang dari satu, yang berarti merupakan excluder. Yoon et al (2006) menjelaskan excluder merupakan sifat dimana tumbuhan membatasi penyerapan logam berat pada lingkungannya baik sedimen maupun air namun ketika masuk ke tubuh tumbuhan maka logam berat akan mudah ditranslokasikan ke bagian tubuh yang lain.

Rendahnya nilai BCF disebabkan oleh kecilnya konsentrasi logam $\mathrm{Hg}$ pada bagianbagian tumbuhan dan tingginya konsentrasi logam $\mathrm{Hg}$ pada sedimen. $\mathrm{BCF}<1$ juga dapat disebabkan karena pengambilan sampel dan analisis logam berat dilakukan hanya satu kali, sehingga hasil penelitian ini hanya merepresentasikan serapan logam berat saat penelitian dilakukan. Seiring dengan bertambahnya waktu dan aktivitas manusia maka serapan pada mangrove juga akan berbeda (Purwiyanto, 2013).

\section{Nilai Translocation Factor (TF)}

Nilai translocation factor (TF) digunakan untuk melihat translokasi logam dari akar ke daun, yang dihitung dengan membagi konsentrasi logam dibagian daun dengan bagian akar. Nilai TF yang diperoleh akan dibandingkan dengan standar nilai TF yang dikemukakan oleh Baker (1981), bahwa tanaman yang memiliki nilai TF > 1 merupakan tanaman yang memiliki mekanisme fitoekstraksi, sedangkan tanaman yang memiliki nilai TF $<1$ merupakan tanaman fitostabilisasi. Nilai TF tanaman Rizhophora mucronata ditunjukan pada tabel 4. 
Tabel 4. Nilai TF Tanaman Mangrove Rizhophora mucronata

\begin{tabular}{cccc}
\hline Stasiun & C daun $_{\text {d }}$ & Cakar $_{\text {a }}$ & Nilai \\
\hline St.I & 0 & 0,237 & 0 \\
St.II & 0 & 0,233 & 0 \\
St.III & 0 & 0,217 & 0 \\
\hline
\end{tabular}

Berdasarkan tabel 4 terlihat nilai $\mathrm{TF}<1$, yang berarti tanaman mangrove Rizhophora mucronata yang terdapat dalam penelitian bersifat fitostabilisasi. Fitostabilisasi merupakan mekanisme dalam fitoremediasi. Cara kerja fitostabilisasi menurut Hamzah dan Pancawati (2013) adalah menggunakan kemampuan akar mengubah kondisi lingkungan. Tumbuhan akan menghentikan pergerakan logam yang diserap dan diakumulasikan oleh akar, kemudian diserap dan diendapkan dalam rizosfer. Lebih lanjut Hidayati (2005) menjelaskan fitostabilisasi menunjukkan bahwa tumbuhan melakukan imobilisasi polutan dengan cara mengakumulasi, mengadsorpsi pada permukaan akar dan mengendapkan polutan pada zona akar. Ini sesuai dengan temuan konsentrasi logam $\mathrm{Hg}$ yang terbanyak terkonsentrasi pada bagian akar dibandingkan dengan kulit batang dan daun.

\section{KESIMPULAN}

Berdasarkan hasil penelitian terkait analisis konsentrasi logam berat merkuri pada mangrove Rizhophora mucronata menunjukan konsentrasi $\mathrm{Hg}$ pada akar lebih tinggi dari kulit batang dan daun. Tingginya konsentrasi $\mathrm{Hg}$ pada akar diduga karena jaringan akar mempunyai interaksi langsung dengan sedimen dan air yang telah terkontaminasi oleh logam berat yang mengendap. Konsentrasi $\mathrm{Hg}$ mangrove $R$. mucronata lebih rendah dari sedimen dan masih dibawah nilai kritis logam $\mathrm{Hg}$ untuk tanaman sebesar 0,3 - 0,5 ppm. Konsentrasi $\mathrm{Hg}$ sedimen masih dibawah standar baku mutu sedimen sebesar $1,0 \mathrm{mg} / \mathrm{kg}$. Berdasarkan perhitungan nilai BCF tanaman mangrove $R$. mucronata dalam penelitian bersifat Excluder $(\mathrm{BCF}<1)$, sedangkan nilai translocation factor $(\mathrm{TF})$ bersifat fitostabilisasi $(\mathrm{TF}<1)$. Ini menunjukan terjadi pembatasan penyerapan logam berat pada lingkungan baik sedimen maupun air oleh $R$. mucronata, namun ketika masuk ke tubuh tumbuhan maka logam berat akan di imobilisasi dengan cara diakumulasi, diadsorpsi pada permukaan akar dan diendapkan pada zona akar.

\section{DAFTAR PUSTAKA}

Alloway, B. J and D. C.Ayres. (1995). Chemical Principle of Environmental Pollution, $2^{\text {nd }}$ Edition. Blackie Academic and Professional, Chapman \& Hall, London. 
Amin, B., Ismail, A., Arshad, A., Yap, C. K and Kamarudin, M. S. (2009). Anthropogenic impacts on heavy metal concentrations in the coastal sediments of Dumai, Indonesia. Environment Monitoring and Assessment, 148,291-305.

Arisandy, K.R., Herawati, E.Y dan Suprayitno, E. (2012). Akumulasi logam berat timbal $(\mathrm{Pb})$ dan gambaran histologi pada jaringan Avicennia marina (forsk.) Vierh di perairan pantai Jawa Timur. J. Penelit. Perikan. 1, 15-25.

Australian and New Zealand Environment and Conservation Council (ANZECC) and Agriculture and Resource Management Council of Australia and New Zealand (ARMCANZ). (2000). Australian and New Zealand Guidelines for Fresh and Marine Water Quality. Volume 1, Australian and New Zealand Environment and Conservation Council. Canberra. 29p.

Baker, A. J. (1981). Accumulators and Excluders-Strategies in The Response of Plants to Heavy Metals. J. Plant Nutrition, 3(1), 643-654.

Feng, X and Qiu, M. (2008). Mercury pollution in Guizhou, Southwestern China-An overview. Science of The Total Environment, 400, pp. 227-237.

Gochfeld, M. (2003). Cases of Mercury Exposure, Bioavailability and absorption. Ecotoxicology and Enviromental. Safety 56, 174-279.

Hamzah, F dan Pancawati, Y. (2013). Fitoremidiasi Logam Berat dengan Menggunakan Mangrove (Phytoremiditation of Heavy Metals Using Mangroves). ILMU Kelaut. Indones. J. Mar. Sci. 18, 203-212.

Hardiani H. (2009). Potensi Tanaman dalam Mengakumulasi Logam $\mathrm{Cu}$ pada Media Tanah Terkontaminasi Limbah Padat Industri Kertas. Berita Selulosa 44 (1) : 27 40.

Hastuti, E. D., Anggoro, S dan Pribadi, R. (2013). Pengaruh Jenis dan Kerapatan Vegetasi Mangrove terhadap Kandungan Cd dan Cr Sedimen di Wilayah Pesisir Semarang dan Demak. Prosiding Seminar Nasional Pengelolaan Sumber daya Alam dan Lingkungan.

He, T.R., Lu, J., Yang, F and Feng, X.B. (2007). Horizontal and vertical variability of mercury species in pore water and sediments in small lakes in Ontario. Sci. Total Environ. 386, 53-64.

Heriyanto, N.M. \& Endro, S. (2011). Penyerapan Polutan Logam Berat (Hg, Pb dan $\mathrm{Cu})$ oleh Jenis-Jenis Mangrove. Jurnal Penelitian Hutan dan Konservasi, 8(2): 177188.

Hidayati, N. (2005). Fitoremediasi dan potensi tumbuhan hiperakumulator. Hayati Journal of Biosciences, 12(1), 35-40.

BIOLOGI SEL (VOL 9 NO 2 EDISI JUL-DES 2020 ISSN 2252-858X/E-ISSN 2541-1225) PAGE 150 
Irsan., Male, Y. T dan Selanno, D. A. (2020). Analisis Konsentrasi Logam Berat Merkuri (Hg) Pada Air, Sedimen dan Kerang Polymesoda erosa di Muara Sungai Waelata dan Sungai Anahoni Kabupaten Buru. Jurnal Chem. Prog, Vol. 13 (1), 31-38.

Jupriyati, R., Soenardjo, N dan Suryono, C.A. (2013). Akumulasi Logam Berat Timbal $(\mathrm{Pb})$ dan Pengaruhnya Terhadap Histologi Akar Mangrove Avicennia marina (Forssk). Vierh. di Perairan Mangunharjo Semarang. UNDIP.

Lakitan B. (2001). Dasar-Dasar Fisiologi Tumbuhan. Raja Grafindo Persada. Jakarta.

Liu, G., Cai, Y and Driscoll, N. O. (2012). Environmental Chemistry And Toxicology Of Mercury. ISBN 978-0-470-57872-8. Copyright c 2012 by John Wiley \& Sons, Inc. All rights reserved.

MacFarlane, G. R., Pulkownik, A., \& Burchett, M. D. (2003). Accumulation and distribution of heavy metals in the grey mangrove, Avicennia marina (Forsk.) Vierh.: biological indication potential. Environmental Pollution. 123(1), 139-151.

Majid, S. N., Khwakaram, A. I., Rasul, G. A. M., \& Ahmed, Z. H. 2014. Bioaccumulation, Enrichment and Translocation Factors of some Heavy Metals in Typha Angustifolia and Phragmites Australis Species Growing along Qalyasan Stream in Sulaimani City/IKR. Journal of Zankoy Sulaimani-Part A. 16(4).

Male, Y. T., Brushett, A. J. R., Pocock, M and Nanlohy, A. (2013). Recent mercury contamination from artisanal gold mining on Buru Island, Indonesia- Potential future risks to environmental health and food safety. Marine Pollution Bulletin 77 (2013) 428-433. Copyright_2013 Published by Elsevier Ltd. All rights reserved. http://dx.doi.org/10.1016/j. marpolbul.2013.09.011. E-mail address: amanda.reichelt-brushett@scu.edu.au.

Natsir1, N. A., Selanno, D. A. J.,, Tupan, Ch. I dan Male, Y. T. (2019). Uji Kandungan Logam Berat Pb Dan Hg Pada Air, Sedimen Dan Lamun (Enhalus acoroides) Di Perairan Teluk Kayeli Kabupaten Buru Provinsi Maluku. Jurnal Biology Science \& Education, Vol 8 (1), 9-20.

Pahalawattaarachchi, V., C.S Purushothaman \& A. Vennila. (2009). Metal Phytoremediation Potensial of Rizhophora mucronata. Indian Journal of Marine Sciences, Vol. 38(2), June 2009, pp. 178-183.

Parvaresh HZ., Abedi P., Farhchi M., Karami N., Khorasani \& Karbassi A. (2010). Bioavalability and Concentration of Heavy Metals in the Sediments and Leaves of Grey Mangrove, Avicennia marina (Forsk.) Vierh, in Sirik Azini Creek, Iran, Biol. Trace Elem. Res. DOI 10.1007/s12011-010-8891-y.

Priyanto B., \& Prayitno, J. (2004). Fitoremediasi sebagai Sebuah Teknologi Pemulihan Pencemaran Khusus Logam Berat. Jurnal Informasi Fitoremediasi. 
Purwiyanto, A. I. S. (2013). Daya Serap Akar dan Daun Mangrove Terhadap Logam Tembaga $(\mathrm{Cu})$ di Tanjung Api-Api, Sumatera Selatan. Jurnal Maspari, 5 (1), 1-5. Sanadi., T.H., Joshian N.W.S., Sandra O.T., Desy, M., Robert, B dan Wilmy, P. (2018). Analisis Logam Berat Timbal (Pb) Pada Akar Mangrove Di Desa Bahowo Dan Desa Talawaan Bajo Kecamatan Tongkaina. Jurnal Pesisir dan Laut Tropis, Vol 2 (1).

Siswanto, D. (2009). Respon Pertumbuhan Kayu Apu (Pistia stratiotes L.) Jagung (Zea mays L.) dan Kacang Tolo (Vigna sinensis L.) terhadap Pencemar Timbal (Pb). Malang: Universitas Brawijaya.

Suheryanto., Poedji, L.H dan Erwin, D. (2013). Kajian Pencemaran Merkuri Total di Perairan Sungai Rupit Musi Rawas Sumatera Selatan. Prosiding Semirata FMIPA Universitas Lampung, 2013: 385-391.

Utami, R., Wini, R dan Kastana, S. (2018). Pemanfaatan Mangrove Untuk Mengurangi Logam Berat Di Perairan. Prosiding Seminar Nasional Hari Air Dunia 2018 Palembang 20 Maret 2018 e-ISSN: 2621-7449, 141-153.

Yoon, J., Cao, X., Zhou, Q., \& Ma, L. Q. (2006). Accumulation of Pb, Cu, and $\mathrm{Zn}$ in native plants growing on a contaminated Florida site. Science of the total environment, 368 (2-3), 456-464. 